\title{
The Effects of Coffee on Conjugation Reactions in Human Colon Carcinoma Cells
}

\author{
Shigeaki Okamura, Keiko Suzuki, Masayo Yanase, Masumi Koizumi, and Hiro-omi Tamura* \\ Kyoritsu University of Pharmacy; Shibakoen, Minato-ku, Tokyo 105-8512, Japan. \\ Received August 21, 2004; accepted October 17, 2004
}

\begin{abstract}
We examined the effect of coffee on conjugation reactions in the human colon carcinoma cell line, Caco-2. After supplementing Caco-2 cultures with both 1-naphthol $(200 \mu \mathrm{M})$ and various concentrations of coffee, the accumulation of 1-naphthyl sulfate and glucuronide in the growth medium was determined by analytical HPLC over a 24-h period. A strong reduction in sulfo-conjugation $(<50 \%$ of the control value) was observed in cells treated with coffee $\left(\mathrm{IC}_{50}=\mathbf{4 . 3 \%}\right)$, but no effect on glucuronic acid conjugation (glucuronidation) was observed. Coffee was also found to inhibit sulfotransferase (SULT) activity towards 1-naphthol in vitro to a similar extent $\left(\mathrm{IC}_{\mathbf{5 0}}=\mathbf{5 . 1 \%}\right)$ as in intact Caco-2 cells, but exhibited no effect upon UDP-glucuronosyl transferase (UGT) activity in vitro. PCR analyses showed no significant changes in the expression of either SULT genes (SULT1A1 and SULT1A3) or UGT genes (UGT1A1 and UGT1A6) following treatment with coffee solutions of up to $5 \%$ in concentration. These results suggest that the consumption of coffee can modify sulfo-conjugation reactions within intestinal epithelial cells, which may possibly affect the bioavailability of therapeutic drugs and the toxicity of environmental chemicals.
\end{abstract}

Key words Caco-2; coffee; conjugation

Coffee is a widely consumed beverage and induces a series of metabolic and pharmacological effects, especially in the digestive tract. Several epidemiological studies have now shown that coffee consumption is associated with a lower risk of certain types of cancers, particularly colorectal cancers. ${ }^{1,2}$ In addition, evidence from a number of animal studies has provided further support for a potential chemoprotective effect of coffee; both coffee and constituents of coffee show protective effects against the action of specific carcinogens such as nitrosoamines and 1,2-dimethylhydrazine. $^{3,4)}$ Several studies have also demonstrated the effects of coffee on hepatic enzymes involved in the detoxification of carcinogens, such as cytochrome P450 1A2 (CYP1A2), UDP-glucuronosyl transferases (UGTs) and glutathione S-transferases (GSTs). ${ }^{5-7)}$ However, little is known about the effects of coffee on intestinal drug metabolizing enzymes.

Previously we have analyzed the effects of various types of tea, such as green, black and herbal teas, upon conjugation reactions in a human colon carcinoma cell line, Caco-2, and found that they show inhibitory activity, particularly against sulfo-conjugation reactions. ${ }^{8)}$ Since sulfo-conjugation has been identified as a key step in the bioactivation of procarcinogens, ${ }^{18-20)}$ it was therefore of interest to know whether coffee showed any effects upon similar conjugation pathways in the human digestive tract. Hence, we investigated the effects of coffee upon conjugation reactions in the Caco-2 cell line, which is a model of human intestinal epithelial cells.

\section{MATERIALS AND METHODS}

Materials All chemicals and reagents used in this study were of a HPLC analytical grade. Caffeine, 1-naphthyl sulfate, 1-naphthyl glucuronide and tetrabutylammonium hydrogen sulfate were purchased from Sigma Chemicals (St. Louis, MO, U.S.A.). Acetonitril was purchased from Wako Chemicals (Tokyo, Japan). Caco-2 cells were obtained at passage 40 from the RIKEN Cell Bank, Japan.

Preparation of Coffee Extract Blended coffee powder was obtained from Brooks Co., Japan. Coffee extract were prepared in a usual way in which $8 \mathrm{~g}$ of powder was extracted with $140 \mathrm{ml}$ hot water $\left(95^{\circ} \mathrm{C}\right)$. The extract was then filtered and divided into small aliquots, and stored at $-80^{\circ} \mathrm{C}$ until use. Undiluted extract was assigned a concentration of $100 \%$ $(\mathrm{v} / \mathrm{v})$ with a dry weight of $8.4 \mathrm{mg} / \mathrm{ml}$.

Cell Culture Caco-2 cells were grown in 12-well plates (Iwaki, Japan) in $1 \mathrm{ml}$ MEM, supplemented with $10 \%$ fetal bovine serum, $2 \mathrm{~mm}$ glutamine, $10 \mathrm{U} / \mathrm{ml}$ penicillin, $10 \mathrm{U} / \mathrm{ml}$ streptomycin and additional non-essential amino acids. The cells were seeded at a concentration of $5 \times 10^{5}$ cells $/ \mathrm{ml}$ and grown until confluence $(5-6 \mathrm{~d})$ in a $37^{\circ} \mathrm{C}$ incubator, in a humidified atmosphere containing $5 \% \mathrm{CO}_{2}$. Cells were then further cultivated for up to three weeks. The media was changed every $4-5 \mathrm{~d}$.

Analyses of 1-Naphthyl Sulfate and Glucuronide Quantitation of 1-napthol conjugates was performed as described previously. ${ }^{8)}$ Briefly, 1-naphthol $(200 \mu \mathrm{M})$ was added to the medium, after which the cells continued to incubate at $37^{\circ} \mathrm{C}$. Aliquots $(50 \mu \mathrm{l})$ of medium were then removed at various timepoints, and $30 \mu \mathrm{l}$ of this mixture was filtered and injected into a HPLC apparatus equipped with an ODS column (Chromolith Performance RP-18e, $100 \times 4.6 \mathrm{~mm}$, Merck). The mobile phase consisted of $10 \mathrm{~mm}$ tetrabutylammonium hydrogen sulfate in water and acetonitril (72.5: 27.5 ), and the flow rate was $1.0 \mathrm{ml} / \mathrm{min}$ with a column temperature of $30^{\circ} \mathrm{C}$. Elution was monitored at $285 \mathrm{~nm}$. The retention times for 1-naphthol, 1-naphthyl sulfate and 1-naphthyl glucuronide were determined to be 11.4, 24.0 and $3.4 \mathrm{~min}$, respectively. The linearity of the standard curves for 1-naphthyl sulfate and glucuronide was observed up to $200 \mu \mathrm{M}$. The effects of coffee on conjugation reactions could then be measured by adding coffee to the culture medium of Caco-2 cells. $\mathrm{IC}_{50}$ values for the concentration-activity curves were calculated using a curve-fit program for Win- 
dows.

Cytosolic Extract and Microsome Preparations from Caco-2 Cells Cells $\left(1-2 \times 10^{7}\right)$ were removed from the culture dishes $\left(75 \mathrm{~mm}^{2}\right)$, washed with phosphate buffered saline, and then homogenized in $1 \mathrm{ml}$ buffer $A(50 \mathrm{~mm}$ Tris-HCl (pH 7.5), $250 \mathrm{~mm}$ sucrose, $0.1 \mathrm{~mm}$ EDTA, $3 \mathrm{~mm}$ 2-mercaptoethanol, $0.1 \mathrm{~mm}$ phenylmethylsulfonyl fluoride, $5 \mu \mathrm{g} / \mathrm{ml}$ antipain, and $5 \mu \mathrm{g} / \mathrm{ml}$ pepstatin). The debris was removed by centrifugation at $3000 \boldsymbol{g}$ for $15 \mathrm{~min}$, after which the supernatant was centrifuged at $105000 \mathrm{~g}$ for $60 \mathrm{~min}$. The clear lysate was used as the cytosolic extract, and the precipitate was used as the microsomal fraction in subsequent experiments.

Assay of P-ST Activity P-ST activity within the cytosolic fractions was determined using $\left[{ }^{35} \mathrm{~S}\right] \mathrm{PAPS}$ as the sulfate donor and 1-naphthol as the sulfate acceptor, according to a slight modification of the procedure of Foldes and Meek. ${ }^{9)}$ Briefly, the reaction mixture $(250 \mu \mathrm{l})$ contained $10 \mathrm{~mm}$ phosphate buffer ( $\mathrm{pH} 7.4$ ), $50 \mu \mathrm{M}$ 1-naphthol, 5.0 $\mu \mathrm{M}\left[{ }^{35} \mathrm{~S}\right] \mathrm{PAPS}$ $(0.1 \mu \mathrm{Ci})$ and cytosolic extract $(50 \mu \mathrm{g}$ of protein). The mixture was incubated at $37^{\circ} \mathrm{C}$ for $30 \mathrm{~min}$ and the reaction was stopped by the addition of $50 \mu \mathrm{l}$ cold $0.1 \mathrm{~m}$ barium acetate. Excess $\left[{ }^{35}\right.$ S]PAPS was precipitated by the addition of $50 \mu \mathrm{l}$ of both $0.1 \mathrm{M} \mathrm{Ba}(\mathrm{OH})_{2}$ and $0.1 \mathrm{M} \mathrm{ZnSO}_{4}$ and removed by centrifugation at $12000 \boldsymbol{g}$ for $5 \mathrm{~min}$. This precipitation procedure was then repeated, and the remaining supernatant $(300 \mu \mathrm{l})$ was transferred to a $3 \mathrm{ml}$ liquid scintillator to determine radioactivity levels. Control reactions were established by omitting the acceptor substrate from the mixture.

Assay of UGT Activity UGT activity was measured as previously described, ${ }^{10)}$ with slight modifications. Briefly, the reaction mixture $(50 \mu \mathrm{l})$ contained $100 \mathrm{~mm}$ Tris- $\mathrm{HCl}(\mathrm{pH}$ 7.4), $10 \mathrm{~mm} \mathrm{MgCl}_{2}, 1 \mathrm{~mm}$ 1-naphthol and a microsome fraction $(100 \mu \mathrm{g}$ of protein). The reactions were initiated by the addition of $0.2 \mathrm{~mm}$ UDP-[U- $\left.{ }^{14} \mathrm{C}\right]$ glucuronic acid $(0.1 \mu \mathrm{Ci})$ and continued for $30 \mathrm{~min}$ at $37^{\circ} \mathrm{C}$. The reactions were stopped by the addition of $100 \mu \mathrm{l}$ ethanol (95\%), and the mixtures were then centrifuged at $1000 \boldsymbol{g}$ for $5 \mathrm{~min}$. Aliquots $(50 \mu \mathrm{l})$ were applied to silica-gel TLC plates $\left(\right.$ Merck $\left.60 \mathrm{~F}_{254}\right)$ and developed in $n$-butanol-acetone-glacial acetic acid-ammonia $(30 \%)$-water $(70: 50: 18: 1.5: 60, \mathrm{v} / \mathrm{v})$. Radioactive compounds were analyzed by a radioimage analyzer (Fuji Film, BAS2000).

RNA Isolation and Reverse Transcription-PCR (RTPCR) Total RNA was isolated from cultured cells by the guanidium thiocyanate phenol-chloroform extraction method. ${ }^{11)}$ First strand cDNA was synthesized from $10 \mu \mathrm{g}$ of total RNA by 1 unit M-MLV reverse transcriptase with oligo(dT) primers, according to the manufacturer's protocol. PCR was carried out, using this cDNA as a template, with AmpliTaq Gold polymerase (Perkin-Elmer). The PCR primers used to amplify human SULT and UGT cDNAs were designed from published sequences. The PCR reaction conditions (30-40 cycles) were as follows: $1 \mathrm{~min}$ at $94{ }^{\circ} \mathrm{C}$, $1.5 \mathrm{~min}$ at $54-58^{\circ} \mathrm{C}$ and $2 \mathrm{~min}$ at $72^{\circ} \mathrm{C}$.

Quantitative-PCR Quantitative real-time-PCR was performed with an ABI-Prism 7700 thermal cycler using a SYBR green PCR core reagent kit (Applied Biosystems, Warrington, U.K.). Samples were denatured at $94{ }^{\circ} \mathrm{C}$ for $10 \mathrm{~min}$, and cDNA products were amplified with 40 cycles of denaturation at $94^{\circ} \mathrm{C}$ for $30 \mathrm{~s}$, then annealing and extension at $60^{\circ} \mathrm{C}$ for $60 \mathrm{~s}$. Calculations of the initial amounts of mRNA were performed according to the cycle threshold method. ${ }^{12)}$ The mRNA levels were normalized to $\beta$-actin levels, which had been quantified by RT-PCR.

\section{RESULTS AND DISCUSSION}

Effects of Coffee on Conjugation Reactions in Caco-2 Cells To determine the effects of coffee on conjugation reactions in intact Caco- 2 cells, we measured the sulfo- and glucuronic acid conjugates of 1-naphthol in the cellular growth media which had been supplemented with $200 \mu \mathrm{M}$ 1 -naphthol in the presence or absence of coffee, as described previously. ${ }^{8,13)}$ As shown in Fig. 1A, 1-naphthyl sulfate and 1-naphthyl glucuronide levels accumulate in the culture medium in a manner that is almost directly proportional to the incubation time. After $24 \mathrm{~h}$ of culture, more than $80 \%$ of the initial 1-naphthol supplement had been converted to either its sulfo- or glucuronic acid conjugate forms (data not shown). Following the addition of coffee into the medium (up to a concentration of 5\%), a decrease in sulfo-conjugation was observed in a dose-dependent manner $\left(\mathrm{IC}_{50}=4.3 \%\right.$ : $0.36 \mathrm{mg}$ extract $/ \mathrm{ml}$ ), whereas no detectable changes were detected in glucuronidation activity (Fig. 1A).

As caffeine is a major component of coffee, and it has many physiological properties, we also analyzed its effects on conjugation activities in Caco- 2 cells. Caffeine was found, however, to show only a weak inhibitory effect on sulfo-conjugation and an even lesser effect on glucuronidation in Caco-2 cells at a dose of $100 \mu \mathrm{M}$ (Fig. 1B). The concentration of caffeine in the coffee extract was calculated to be $1-2 \mathrm{~mm}$ based upon previously published data, demonstrating that $5-10 \%$ of the total constituents of coffee are in fact caffeine. Hence, $100 \mu \mathrm{M}$ caffeine is equivalent to an approximately $10-20 \%$ solution of coffee extract. From these data we conclude that caffeine is not the component in coffee that is responsible for its inhibitory action on conjugation reactions.

Effects of Coffee on SULT and UGT Activities in Vitro To elucidate the underlying mechanism(s) by which coffee affects conjugation activities in Caco- 2 cells, we next measured its effects on the enzymatic activities of SULT and UGT towards 1-naphthol in vitro. As shown in Fig. 2A, exposure to coffee strongly inhibits in vitro SULT activity $\left(\mathrm{IC}_{50}=5.1 \%\right.$ : $0.43 \mathrm{mg}$ extract $\left./ \mathrm{ml}\right)$, but shows no significant effects on UGT activity. The $\mathrm{IC}_{50}$ values in these cases were almost identical to those measured in intact cells, suggesting that the inhibitory effect of coffee on the sulfo-conjugation of 1-naphthol in Caco-2 cells might be due to direct interaction with the enzyme proteins inside the cell. Further analysis will need to be undertaken to clarify the molecular basis of this inhibition.

Effects of Coffee on SULT and UGT Gene Expression As recent studies have demonstrated that coffee components can affect several drug metabolizing enzymes in mammalian cells by regulation of their gene expression, ${ }^{6,7)}$ we investigated the effects of coffee on the expression of both SULT and UGT genes. In humans, several subfamilies of SULT and UGT genes have now been identified, and among these we selected SULT1A1, SULT1A3, UGT1A1 and UGT1A6, due to their substrate specificities. The expression levels of each 
(A)

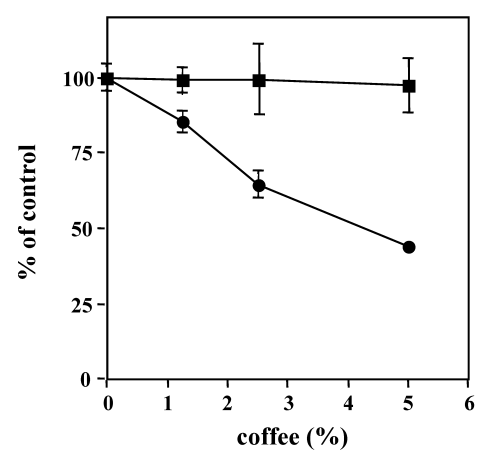

(B)

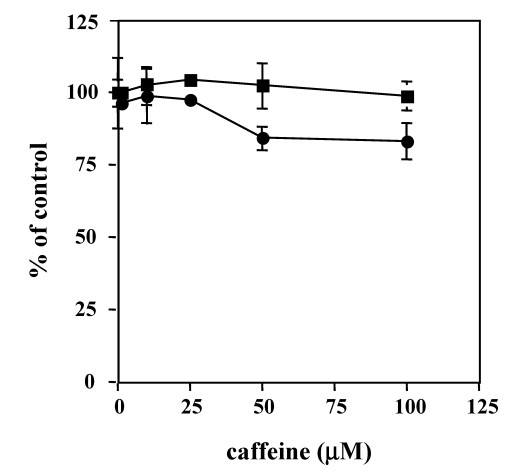

Fig. 1. Effects of Coffee (A) and Caffeine (B) on Conjugation Reactions in Caco-2 Cells

Cell cultures were treated with $200 \mu \mathrm{M}$ 1-naphthol and the indicated amounts of coffee (A) and caffeine (B), respectively. After $24 \mathrm{~h}$, the quantities of 1-naphtyl sulfate (circles) and glucuronide (squares) in the media were determined by HPLC and are represented as a percentage of the control levels. Each of the given values are the means with S.D. from three independent experiments. The mean values of the controls are $45 \mu \mathrm{M}$ for 1-naphthyl sulfate and $70 \mu \mathrm{m}$ for 1-naphthyl glucuronide.

(A)

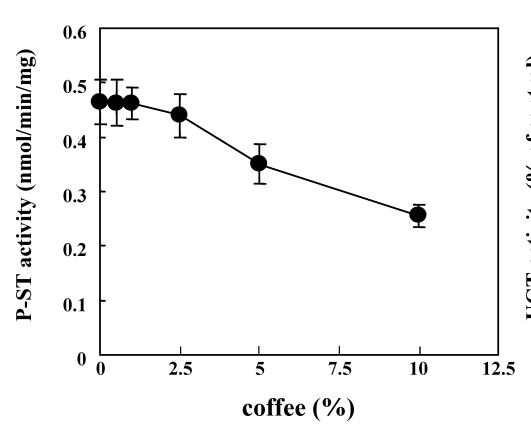

(B)

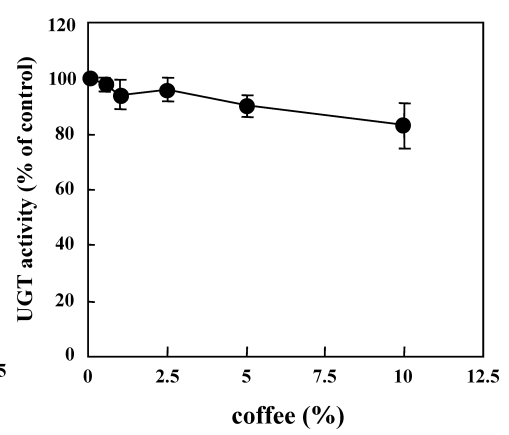

Fig. 2. Effects of Coffee on the in Vitro Activities of SULT (A) and UGT (B)

The SULT and UGT activities of 1-naphthol were measured in the presence or absence of coffee at the indicated concentrations $(0-10 \%)$, using a $50 \mu \mathrm{g}$ cytosolic protein fraction for SULT and a $100 \mu \mathrm{g}$ microsome preparation for UGT. The UGT activity levels are represented as a percentage of the control, without coffee treatment. The IC ${ }_{50}$ value of coffee treatment on SULT activities was determined to be $5.1 \%$ using a curve-fit program for Windows. All given values represent the means with S.D. from three independent experiments.

of these genes was subsequently monitored by RT-PCR after treatment with $5 \%$ coffee for $24 \mathrm{~h}$. As shown in Fig. 3, no obvious changes were detected in the levels of SULT or UGT expression tested, and this was confirmed by quantitative real-time PCR analysis (data not shown).

Recent studies have demonstrated the induction of different isoforms of the UGT1A subfamily in Caco-2 cells by dietary flavonoids, such as chrysin and quercetin. ${ }^{14,15)}$ Coffee also contains several phenolic compounds with antioxidant properties, and its total polyphenol content has been reported to range from 200 to $550 \mathrm{mg}$ per serving. ${ }^{16,17)}$ Such phenolic antioxidant compounds in coffee may induce UGT1A6 expression in Caco-2 cells, but no induction of UGT1A1 or UGT1A6 genes was observed in our experiments. It is possible, however, that the incubation periods $(24 \mathrm{~h})$ adopted in our experiments were not sufficiently long to induce UGT1A gene expression.

In this report we describe the effects of coffee on conjugation reactions in a human intestinal model cell line, Caco-2. We demonstrate that coffee strongly inhibits sulfo-conjugation in these cells, whereas caffeine, a major component of coffee, shows little significant effect on SULT activity either in vivo or in vitro. Neither coffee nor caffeine, therefore, show any effects on UGT activity in Caco-2 cells. It is cur-

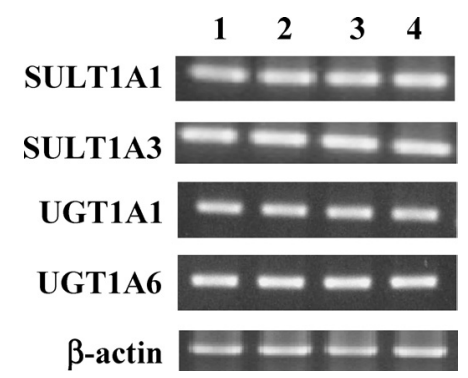

Fig. 3. RT-PCR Analyses of SULT1 and UGT1 Gene Expression Levels

Total RNA $(5 \mu \mathrm{g})$ was isolated from Caco- 2 cell cultures supplemented with coffee $(0,1.25,2.5$ or $5 \%$ solutions) for $24 \mathrm{~h}$ and then subjected to RT-PCR analyses for SULT1A1, SULT1A3, UGT1A1 and UGT1A6. Lane 1, $0 \%$ coffee; lane $2,1.25 \%$ coffee; lane $3,2.5 \%$ coffee; lane $4,5 \%$ coffee. PCR cycle numbers were 24 for the UGTs and $\beta$-actin genes and 30 for the SULT genes.

rently uncertain which of the components of coffee is in fact responsible for the inhibition of SULT activity but phenolic components are the most likely candidates due to the substrate specificity of SULTs. As sulfo-conjugation has been shown to be responsible for the bioactivation of proximal carcinogens in many studies, ${ }^{18-20)}$ this inhibitory feature of coffee may be related to the observed anticancer effects of coffee consumption. Additional characterizations should 
therefore be carried out to further clarify the molecular basis of the effects of coffee on conjugation reactions.

Acknowledgements This work was supported in part by a Grant-in-Aid from the Ministry of Education, Culture, Sports, Science and Technology of Japan.

\section{REFERENCES}

1) Inoue M., Tajima K., Hirose K., Jpn. Cancer Causes and Control, 9, 209-216 (1998).

2) Giovannucci E., Am. J. Epidemiol., 147, 1043-1052 (1998).

3) Nishikawa A., Tanaka T., Mori H., J. Nutr. Growth Cancer, 3, 161166 (1986).

4) Gershbein L. L., Anticancer Res., 14, 1113-1116 (1994).

5) Turesky R. J., Richoz J., Constable A., Curtis K. D., Dingley K. H., Turteltaub K. W., Chem. Biol. Interact., 145, 251-265 (2003).

6) Cavin C., Holzhauser D., Constable A., Huggett A. C., Schilter B., Carcinogenesis, 19, 1369-1375 (1998).
7) Cavin C., Holzhaeuser D., Scharf G., Constable A., Huber W. W., Schilter B., Food Chem. Toxicol., 40, 1155-1163 (2002).

8) Okamura S., Tamura H., J. Health Sci., 50, 189-192 (2004).

9) Foldes A., Meek J. L., Biochim. Biophys. Acta, 327, 365-374 (1973).

10) Bansal S. K., Gessner T., Anal. Biochem., 109, $321-329$ (1980).

11) Chomczynski P., Sacchi N., Anal. Biochem., 162, 156-159 (1987).

12) Higuchi R., Fockler C., Dollinger G., Watson R., Biotechnology, 11, 1026-1030 (1993).

13) Isozaki T., Tamura H., Biol. Pharm. Bull., 24, 1076-1078 (2001).

14) Galijatovic A., Walle U. K., Walle T., Pharm. Res., 17, 21-26 (2000).

15) Walle T., Otake Y., Galijatovic A., Ritter J. K., Walle U. K., Drug Metab. Dispos., 28, 1077-1082 (2000).

16) Bravo L., Nutr. Res., 56, 317-333 (1998).

17) Natella F., Nardin M., Gianetti I., Dattilo C., Scaaini C., J. Agric. Food Chem., 50, 6211-6216 (2002).

18) Yamazoe Y., Abu-Zeid M., Gong D., Ataiano N., Kato R., Carcinogenesis, 10, 1675-1679 (1989).

19) Glatt H., FASEB J., 11, 314-321 (1997).

20) Edenharder R., Sager J. W., Glatt H., Muckel E., Platt K. L., Mutat. Res., 521, 57-72 (2002). 